\title{
Christ, Torah, and the Faithfulness of God: The Concept of Supersessionism in "The Gifts and the Calling"'
}

\author{
MATTHEW TAPIE \\ matthew.tapie@saintleo.edu \\ Saint Leo University, Saint Leo, FL 33574
}

This article was generated from the February 2016 Saint Joseph's University "Consultation on the Newest Statements about the Christian-Jewish Relationship."

\section{Introduction}

The current scholarly discourse regarding the Church's relationship to the Jewish people is dominated by one word: supersessionism. With the December 2015 publication of "The Gifts and the Calling of God are Irrevocable", (G\&C), the Pontifical Commission for Religious Relations with the Jews (CRRJ) joined a chorus of Jewish and Christian scholars that have long called for the repudiation of supersessionism. ${ }^{3}$ Though Catholic teaching about Jews and Judaism after Nostra Aetate has developed according to what G\&C refers to as a "new theological framework" that emphasizes the positive and ongoing theological significance of God's covenant with the Jewish people, the CRRJ had not previously explicitly rejected supersessionism. ${ }^{4}$ As I show below, G\&C makes this rejection explicit.

\footnotetext{
${ }^{1}$ Portions of this article were originally written for a paper entitled, "Has the Church Replaced the Jewish People in God's Divine Plan?: Reflections for Dialogue and Trust between the Two Communities," delivered at the $28^{\text {th }}$ Annual Catholic-Jewish Colloquium, with response by Rabbi Peter Hass, April 7, 2016, at the Center for Pastoral Leadership of the Catholic Diocese of Cleveland, Wickliffe, Ohio. Additionally, sections two and three are modified versions of material published in part of chapter one of Matthew Tapie, Aquinas on Israel and the Church: The Question of Supersessionism in the Theology of Thomas Aquinas (Eugene, OR: Pickwick, 2014).

2 “"The Gifts and the Calling of God Are Irrevocable' (Rom 11:29)--A Reflection on Theological Questions Pertaining to Catholic-Jewish Relations (10 December 2015)," accessed March 29, 2016, http://www.vatican.va/roman_curia/pontifical_councils/chrstuni/relations-jewsdocs/rc_pc_chrstuni_doc_20151210_ebraismo-nostra-aetate_en.html. Here after, G\&C.

${ }^{3}$ The most influential example of this call to repudiate has come from R. Kendall Soulen's The God of Israel and Christian Theology (Minneapolis: Fortress Press, 1996). See also David Novak, Talking with Christians: Musings of a Jewish Theologian (Grand Rapids, MI: William B. Eerdmans Publishing Co., 2005), 8.

${ }^{4} \mathrm{G} \& \mathrm{C}$, Preface.
} 
While the refutation of supersessionism is a positive development, the adoption of the term also presents a difficulty. There is confusion about what problematic teaching, exactly, should be avoided. Although the repudiation of "supersessionism" is now widespread among Christians, careful use of the term is not. Some contend that the term should be jettisoned because it is too ambiguous and often seems to function as a term of abuse. ${ }^{5}$ Some scholars argue that a "mild" supersessionism - defined as the idea that Christ "goes beyond Judaism"-is acceptable, and is in fact unavoidable for Christians. ${ }^{6}$ For others, supersessionism is merely one manifestation of doctrinal disagreements among members of different religious traditions (namely, Christianity and Judaism). Each of these views suggests that the rejection of supersessionism for which G\&C calls is impossible, unnecessary, or both. Since G\&C also calls for deepening the theological dimension of Catholic-Jewish dialogue, it seems appropriate to address the confusion surrounding the term. Is the word "supersessionism" simply an epithet? Is it a term for an expected but intractable disagreement between Christians and Jews? Or does the word specify a serious theological problem that can be identified in Christian teaching, and therefore help the Catholic-Jewish dialogue?

The aim of this essay is to analyze G\&C's usage of the word "supersessionism," identifying both how the document's treatment of the term is helpful as well as where further precision is needed. I argue that while G\&C provides important guidance for theological reflection, the document does not identify and discuss supersessionism with necessary precision.

I proceed in four steps. First, I set the document in the context of recent Catholic reflection on Jews and Judaism and identify what problem the CRRJ seems to refer to in its usage of supersessionism. I also show how G\&C's usage is both helpful and unhelpful. In the second and third parts, I draw upon the thought of the French-Jewish historian Jules Isaac, who encouraged Saint Pope John XXIII to call for a statement on the Jews, and the Methodist theologian R. Ken-

\footnotetext{
${ }^{5}$ Stephen E. Fowl, Engaging Scripture: A Model for Theological Interpretation (Eugene, OR: Wipf \& Stock, 2008), 129. "In general, the vast variety of ways this term can be used renders it less than helpful as a description of any particular pattern of reading. Instead, both within the academy and most contemporary churches, to call an interpretative proposal 'supersessionist' is to invoke a term of abuse."

${ }^{6}$ David Novak, Talking with Christians, 164. According to Novak, mild supersessionism is the idea that Christianity "goes beyond" Judaism. For Novak, Edith Stein's rationale for conversion to Christianity is an example of mild supersessionist logic, a logic that Novak thinks is similar to Alasdair MacIntyre's claim that one may find the solution to their own tradition's intellectual problems in another tradition: “. . . a judgment that by the standards of one's own tradition the standpoint of the other tradition offers superior resources for understanding the problems and issues which confront one's own tradition." Alasdair MacIntyre, Whose Justice, Which Rationality (Notre Dame, IN: University of Notre Dame Press, 1988), 370. Mild supersessionism is the view that another tradition is "less rich than another." Novak concludes that this mild form is acceptable since it need not denigrate Judaism: "Christian supersessionism need not denigrate Judaism . . Christian supersessionism can still affirm that God has not annulled His everlasting covenant with the Jewish people."

${ }^{7}$ David Berger, "On Dominus Iesus and the Jews," in Persecution and Polemic: Essays in JewishChristian Relations (Boston, MA: Academic Studies Press, 2010), 381-82.
} 
dall Soulen, whose writings have significantly contributed to the field of JewishChristian relations. I will demonstrate how their critical remarks about a particular Christian teaching regarding Christ's fulfillment of Jewish law greatly clarifies the language of supersessionism for contemporary Catholic-Jewish relations. Fourth, I highlight insights of the late Jewish theologian Michael Wyschogrod to illustrate how the teaching that Christ's fulfillment of the law renders the Jews' continued observance of it obsolete presents serious theological problems. Can we do what G\&C asks us to do? Can we repudiate supersessionism? I argue that only after we see the problem clearly can we begin to search for a solution.

\section{God's Irrevocable Covenant with the Jewish People and the Repudiation of Supersessionism in "The Gifts and the Calling of God are Irrevocable"}

I want to begin my analysis of supersessionism in G\&C with attention to how the document relates to Catholic theological reflection in general, and Catholic teaching on God's ongoing covenant with the Jewish people in particular. Here, I survey some examples of supersessionism in Catholic theological discourse and then examine how G\&C wrestles with questions that were raised by the teaching of Saint Pope John Paul II. Finally, I analyze each reference to supersessionism and related words ("supersede" and "replace") in G\&C, with the aim of discovering what theological problem these words are meant to identify.

The concept of supersessionism is not new to Catholic theological discourse. In the last two decades of the twentieth century, it became pervasive in theological and biblical scholarship, in Catholic as well as Protestant circles. The term "supersessionism" is now used in contemporary theology to designate problematic Christian claims about Judaism. "With respect to Judaism," writes Richard John Neuhaus, "Christians today are exhorted to reject every form of supersessionism, and so we should. To supersede means to nullify, to void, to make obsolete, to displace."8 Reflecting on the impact of John Paul II's positive contributions to Jewish-Christian relations, George Weigel commented that the pope's teaching "challenged Catholics who had never rid themselves of the last vestiges of the belief that God's redemptive action in Christ had superseded, indeed abrogated, the covenant with Abraham." Scholars now stress that Christ and the Church do not supersede Israel. In a way similar to the line of thought in G\&C, scholars seek to affirm the ongoing role of the Jewish people in salvation history: "Christ and his Church do not supersede Judaism, but they do continue and fulfill the story of which we are both part," writes Neuhaus. ${ }^{10}$ However, Mary C. Boys has suggested that supersessionism is "alive and well" whenever we hear claims such as the following: the God of the Old Testament is a God of wrath; the God of the New Testament is a God of love; the Jews rejected Jesus as their messiah;

\footnotetext{
${ }^{8}$ Richard John Neuhaus, American Babylon (New York, NY: Basic Books, 2009), 174-5.

${ }^{9}$ George Weigel, Witness to Hope (New York, NY: Harper Perennial, 2005), 515.

${ }^{10}$ Neuhaus, 175.
} 
and self-righteous and hypocritical Pharisees show how legalistic Judaism had become in Jesus' day. ${ }^{11}$

G\&C reiterates the theme that affirmation of God's ongoing covenant with the Jews entails the rejection of supersessionism. Significantly, G\&C affirms an important theological leitmotif in Catholic teaching on Jews and Judaism, namely, the teaching that God's covenant with the Jewish people is irrevocable. Nostra Aetate, no. 4 strongly implies this teaching. ${ }^{12}$ But as Gavin D'Costa points out, the teaching is only clearly established in Saint Pope John Paul II's thought, especially his 1980 Mainz speech, in which he paraphrases St. Paul's words in Romans 11:29, saying, "the Old Covenant [is] never revoked by God." ${ }^{13}$ The teaching that God's covenant with the Jews is irrevocable was also confirmed in the 1993 Catechism of the Catholic Church (121): "The Old Covenant has never been revoked." ${ }^{, 14}$ Bruce Marshall has highlighted the theological significance of this theme in an important essay entitled, "Elder Brothers: John Paul II's Teaching on the Jewish People as a Question to the Church." ${ }^{15}$ As the subtitle of Marshall's essay indicates, Saint Pope John Paul II's emphasis on the ongoing theological significance of the first covenant poses a challenge: "How should Christians understand and embrace John Paul II's teaching that the Jews are permanently God's people?" ${ }^{16}$ G\&C insists that one traditional Christian position on the status of God's covenant with the Jews - that this covenant is now fulfilled and cancelled for Jews who do not believe in Christ - must be repudiated. G\&C seems to have this sort of traditional position in mind when it repeatedly rejects supersessionism or replacement theology. D'Costa sums up the major implication of Saint Pope John Paul II's affirmation of God's ongoing covenant with the Jews, which G\&C seems to highlight: "Catholic theologies that run counter to this Pauline teaching of 'irrevocability,' such as the theologies of supersessionism, replacement and annulment, are now themselves superseded, replaced and

\footnotetext{
${ }^{11}$ Mary C. Boys, Has God only One Blessing? (New York, NY: Paulist Press, 2000), 8.

${ }^{12}$ Philip A. Cunningham, "The Road Behind and the Road Ahead: Catholicism and Judaism," in $\mathrm{Ca}$ tholicism and Interreligious Dialogue, ed. James Heft (Oxford University Press, USA, 2011), 31. Nostra Aetate reinforced the idea that the Jewish people remain dear to God (Romans 11) by citing Romans 9:4-5 in the present tense: "They are Israelites . . . to them belong the glory, the covenants, the giving of the law ...." A premodern antecedent to this important present tense emphasis of Romans 9:4 can be found in St. Thomas Aquinas's Commentary on Romans. Aquinas even diverges from the standard biblical commentary of his day, the Glossa ordinaria, which is careful to state that the covenant mentioned in Romans 9:4 refers to "the New Testament" covenant, not the old. Tapie, Aquinas on Israel and the Church, 103.

${ }^{13}$ Pope John Paul II, “Address to Representatives of the West German Jewish Community," Mainz, 1980,http://www.ccjr.us/dialogika-resources/documents-and-statements/roman-catholic/pope-johnpaul-ii/297-jp2-80nov17. The text from Romans reads, "For the gifts and the call of God are irrevocable" (Romans 11:29, NABRE).

${ }^{14}$ Catechism of the Catholic Church, 2nd Revised \& enlarged edition (Vatican City/Washington, DC: Libreria Editrice Vaticana, 2000).

${ }^{15}$ Bruce Marshall, "Elder Brothers: John Paul II's Teaching on the Jewish People as a Question to the Church," in John Paul II and the Jewish People: A Christian-Jewish Dialogue, ed. Dalin David and Matthew Levering (Lanham, MD: Rowman \& Littlefield Publishers, Inc., 2007), 113-29.

${ }^{16}$ Marshall, 120.
} 
annulled." ${ }^{17}$ It seems that G\&C views the affirmation of God's irrevocable covenant with the Jewish people by Saint Pope John Paul II and the Catechism of the Catholic Church effectively repudiated supersessionism. But what exactly, according to $\mathrm{G} \& \mathrm{C}$, was repudiated?

In $\mathrm{G} \& \mathrm{C}$, the concern to repudiate supersessionism, also referred to as replacement theology, is especially prominent in parts two and four of the document, two of its largest. Part two focuses on the special theological status of the Jewish-Catholic dialogue. Part four treats the relationship between the Old and New Testaments and the Old and New Covenants. In these sections, "replacement theology" is often used interchangeably with "supersessionism" (e.g., $\S 17-18) .{ }^{18}$ The terms "superseded" (§28), "obsolete" (\$28), and "annulment" (§32) appear in Part 4, "The Relationship between the Old and New Testament and the Old and New Covenant."

The term "supersessionism" itself occurs only once $(\S 17)$ in G\&C, in a paragraph that contains perhaps the most illuminating statement for analyzing whether the term is helpful for Catholic-Jewish dialogue:

On the part of many of the Church Fathers the so-called replacement theory or supersessionism steadily gained favor until in the Middle Ages it represented the standard theological foundation of the relationship with Judaism: the promises and commitments of God would no longer apply to Israel because it had not recognized Jesus as the Messiah and the Son of God, but had been transferred to the Church of Jesus Christ which was now the true 'new Israel,' the new chosen people of God.

This is the closest G\&C comes to giving a definition of supersessionism: "the promises and commitments of God would no longer apply to Israel because it had not recognized Jesus as the Messiah and the Son of God." 19

It is especially noteworthy that G\&C identifies this "supersessionism" as a problematic teaching of "many of the Church Fathers" that became standard in the Middle Ages. This is not the first time the CRRJ has advocated that a patristic teaching about the Jews must be left behind. In the 1985 document "Notes on the Correct Way to Present the Jews and Judaism," the CRRJ developed the teaching in Nostra Aetate no. 4 that the Jews "remain dear to God," by stating that the Jewish people represent a faithful "witness" to God: "The history of Israel did not end

\footnotetext{
${ }^{17}$ D'Costa's remarks are from a forthcoming article in European Judaism on "'The Gifts and the Calling of God are Irrevocable,"” which he was kind enough to share with me.

${ }^{18}$ The two terms are frequently used interchangeably in theological discourse concerning JewishChristian relations. R. Kendall Soulen points out that supersessionism is substantially equivalent to the term replacement theology since "both [terms] designate a theological perspective that interprets Christian faith generally and the status of the Church in particular so as to claim or imply the abrogation or obsolescence of God's covenant with the Jewish people" (R. Kendall Soulen, "Replacement theology," in Edward Kessler and Neil Wenborn, eds., A Dictionary of Jewish-Christian Relations [Cambridge, UK: Cambridge University Press, 2008], 375).

${ }^{19} \mathrm{G} \& \mathrm{C}, \S 17$.
} 
in 70 A.D. It continued...in numerous Diaspora [communities] which allowed Israel to carry to the...world a witness - often heroic — of its fidelity to the one God." ${ }^{20}$ This in essence inverts the traditional claim, developed especially by St. Augustine, that Jews were scattered throughout the Diaspora as a punishment by God and in order to preserve the sacred texts he believed testified to Christ. ${ }^{21}$ Though St. Augustine's claim is not cited explicitly, the CRRJ states that the Church must set this concept of the Jews as Christian witnesses aside: "We must...rid ourselves of the traditional idea of a people punished, preserved as a living argument for Christian apologetic." 22 Though St. Augustine is unnamed, his influential teaching is clearly in view. G\&C's use of the term supersessionism in $\S 17$ can be seen to extend this teaching of the CRRJ from 1985 Notes 6.1. The idea that God's covenant with the Jewish people has been punitively revoked because of the sin of unbelief in Christ is a premise in the Augustinian argument that the Jewish people are now dispersed throughout the world in order to testify to the truth that the Old Testament prophecies about Christ are not contrived. The inversion of this Augustinian witness doctrine in 1985 Notes, along with the rejection of the deicide charge in Nostra Aetate no. 4, represents the repudiation of one of the most influential forms of replacement theology. It is a significant step forward for the CRRJ to identify this teaching as supersessionist.

However, this definition of supersessionism does have a shortcoming. The CRRJ seems to reduce the term only to the punitive form of supersessionism, which implies the revoking of God's covenant with the Jews as punishment for the sin of unbelief. This reduction is a common problem in Christian theological discourse about supersessionism. ${ }^{23}$ Limiting supersessionism to encompass only the belief that God punitively revoked the covenant with the Jews due to their unbelief in Christ misses a more pernicious but subtle replacement theology, which R. Kendall Soulen has identified as "economic supersessionism." ${ }^{24}$ Economic supersessionism is the Christian claim that Christ fulfills the ceremonial law

\footnotetext{
20 "Notes on the correct way to present the Jews and Judaism in preaching and catechesis in the Roman Catholic Church," sec. 6.1. Commission for Religious Relations with the Jews, June $24^{\text {th }}, 1985$, accessed March 29, 2016, http://www.vatican.va/roman_curia/pontifical_councils/chrstuni/relationsjews-docs/rc pc chrstuni doc 19820306 jews-judaism en.html. Hereafter, "Notes."

21 "We see and know that it is in order to bear this witness - which they involuntarily supply on our behalf by possessing and preserving these same books - that they themselves are scattered among all peoples, in whatever direction the Church of Christ expands" (Augustine, De Civitate Dei, 18.46, ed. George E. McCracken et al.; 7 vols., Loeb Classical Library [Cambridge, MA: Harvard University Press, 1957-60], 6:50-51). See also Paula Fredriksen's explanation of the testamentary doctrine: "Scattered throughout the empire the Jews guard 'the books for the sake of the church, bearing the Law and the Prophets, and testifying to the doctrine of the church, so that we honor in the sacrament what they disclose in the letter" [Paula Fredriksen, Augustine and the Jews: A Christian Defense of Jews and Judaism (New York, NY: Doubleday Religion, 2008), 276-7].

22 "Notes," sec. 6.1.

${ }^{23}$ See chapter one of Matthew Levering, Christ's Fulfillment of Torah and Temple: Salvation According to Thomas Aquinas (Notre Dame, IN: University of Notre Dame Press, 2002). Supersessionism is solely identified with a revoking of the covenant.

${ }^{24}$ Soulen, The God of Israel and Christian Theology, 29-30.
} 
(circumcision, Sabbath, and dietary laws) in such a way that Jewish observance of the ceremonial law is obsolete after the passion, with the result that God replaces Israel with the Church. ${ }^{25}$ For example, economic supersessionism is clearly at work in the commonplace medieval concept of the cessatio legalium (cessation of the law) after Christ. ${ }^{26}$ The teaching on the cessatio legalium was "almost universally affirmed by medieval Christian authors. ${ }^{27}$

It might be helpful to briefly highlight the similarities and differences in these two types of supersessionism. Economic supersessionism and punitive supersessionism share the conclusion that the Church replaces the Jews as God's elect community. Punitive and economic supersessionism, however, differ on the "how" of the replacement. Economic supersessionism assumes the Jews are no longer God's elect because the Jewish law is fulfilled and obsolete. Punitive supersessionism assumes the Jews are no longer God's elect because God is punishing them for rejecting Christ. It is this latter concept that is clearly assumed in $\mathrm{G} \& \mathrm{C} \S 17$. Both forms of supersessionism result in the replacement of the people of Israel but arrive at this destination via different routes. ${ }^{28}$

The teaching that Catholics must reject the idea that the covenant with the Jews is revoked is welcome, but omits the economically supersessionist Christian claim that Christ's fulfillment of Jewish law renders it obsolete for Jews. Nonetheless, the CRRJ has directed the Catholic-Jewish dialogue to the subject of supersessionism as it relates to the Middle Ages, and this is an important step.

After the first reference to supersessionism in $\S 17$ of G\&C, a second shortcoming emerges as the language of supersession and replacement becomes more abstract. In each case, the idea of Christianity superseding Judaism is rejected, yet the terms employed are so varied (old and new covenants, Church and Synagogue, Church and Israel, Christological exegesis, and Old and New Testament writings) that the concept of superseding is blurred. This is evident in the following occurrences: "A replacement or supersession theology which sets against one another two separate entities, a Church of the Gentiles and the rejected Synagogue whose place it takes, is deprived of its foundation" (\$17); "The Church does not replace the people of the God of Israel, since as the community founded

\footnotetext{
${ }^{25}$ Tapie, Aquinas on Israel and the Church, 9.

${ }^{26}$ I discuss this medieval teaching at length in Aquinas and Israel and the Church.

${ }^{27}$ Richard Schenk, "Views of the Two Covenants in Medieval Theology," Nova et Vetera 4, no. 4 (2006): 895.

${ }^{28}$ A third form of supersessionism identified by Soulen is "structural." Structural supersessionism is an approach to the biblical narrative that renders the Old Testament largely indecisive for shaping conclusions about how God's redemptive purposes in Christ engage creation in universal and enduring ways. Israel's history is nothing more than a particular prefigurative moment sandwiched between more important, universal, and spiritual aims of God's creation and redemption of humankind. However, structural supersessionism is more a consequence of supersessionism than supersessionism itself. That Israel's narrative no longer shapes God's purposes in engaging creation in a decisive way seems to be a conclusion that follows from the economically supersessionist premise that God's only purpose for Israel was to foreshadow universal redemption in Christ. After the passion the literal meaning of the narrative of the Old Testament no longer shapes God's redemption of the world in a decisive way (Soulen, The God of Israel and Christian Theology, 31-2).
} 
on Christ it represents in him the fulfillment of the promises made to Israel. This does not mean that Israel, not having achieved such a fulfillment, can no longer be considered to be the people of God" $(\$ 23)$; "The new covenant can never replace the old but presupposes it and gives it a new dimension of meaning . . ." (\$27). In each of these examples, the concept of replacement recurs (and is rejected) but the subject replaced by the Church varies from "Synagogue" to "Israel" to "the people of God." Additionally, traditional Christian logic behind the common medieval teaching on the cessation of the law (that clearly specifies causes and effects of replacement) is not mentioned.

In paragraphs 28,30 , and 32 of $\mathrm{G} \& \mathrm{C}$, the subject of replacement expands to include writings, testaments, and covenant. All of these paragraphs draw directly from a portion of Cardinal Kurt Koch's address for the tenth annual meeting of the Council of Centers on Jewish-Christian Relations entitled "Theological Questions and Perspectives in Jewish-Catholic Dialogue." G\&C cites the address word for word: ". . . the New Testament writings have not superseded the older writings and nullified them"; and ". . Christological exegesis can easily give rise to the impression that Christians consider the New Testament not only as the fulfillment of the Old but at the same time as a replacement for it"; "The New Covenant for Christians is therefore neither the annulment nor the replacement, but the fulfillment of the promises of the Old Covenant." The language of replacement in G\&C therefore draws heavily from Cardinal Koch's work, as well as that of Cardinal Kasper, whom Koch cites in his "Theological Questions" address. $^{29}$ That the concept is so prominent in G\&C seems to be an indication of how the theological insights of these two CRRJ presidents strongly influence the document. $^{30}$

Despite these shortcomings in G\&C, the CRRJ takes two important steps. First, G\&C provides a definition of what we might refer to as punitive supersessionism, which has not previously been defined by the CRRJ. Although abstract language plagues most usages of "supersede" and related words in the document, the authors helpfully point to the problem of punitive supersessionism when they define supersessionism as "the promises and commitments of God would no longer apply to Israel because it had not recognized Jesus as the Messiah and the Son of God...." Second, the CRRJ has provided a clear statement that this super-

\footnotetext{
${ }^{29}$ Kurt Cardinal Koch, "The International Dialogue between the Catholic Church and the Jews since Nostra Aetate," May 20, 2015, accessed March 29, 2016 and available from the Council of Centers on Jewish-Christian Relations resource website, http://www.ccjr.us/dialogika-resources/documents-andstatements/roman-catholic/kurt-cardinal-koch/1374-koch-2015may20. Koch cites Cardinal Kasper's foreword to Christ Jesus and the Jewish People Today: New Explorations of Theological Interrelationships, ed. Philip A Cunningham, Joseph Sievers, et al., (Grand Rapids, MI.: William B. Eerdmans Pub., 2011), xiv. The idea that God's covenant with the Jews has been replaced, abrogated, or is obsolete is especially prominent in Walter Cardinal Kasper's 2004 address, "The Relationship of the Old and the New Covenant as One of the Central Issues in Jewish-Christian Dialogue." Accessed March 29, 2016 and also available from the Council of Centers on Jewish-Christian Relations resource site, http://www.ccjr.us/dialogika-resources/documents-and-statements/roman-catholic/kasper/652kasper04dec6-1.

${ }^{30}$ See the annotated version of G\&C in this volume of $S C J R$.
} 
sessionist concept exists in the medieval tradition. Such a reference to the medieval tradition makes it more difficult for some to dismiss supersessionism as a term of abuse or as anachronistic.

One last feature I want to mention about the usage of the term "supersessionism" in G\&C is that the CRRJ clearly wants to affirm the traditional Catholic teaching that Christ is the fulfillment of God's promises to Israel. However, CRRJ also wants to reject the traditional view of the implications of this fulfillment for Jews: punitive supersessionism. This is made clear in §27: "The New Covenant does not revoke the earlier covenants, but it brings them to fulfillment." In other words, it seems that there is a desire to affirm that Christ fulfills the old covenant without also canceling it. G\&C seems to me to be an attempt to repudiate what we might call models of "fulfillment and cancellation." In such models, Christ's fulfillment of God's promises to Israel entails that God no longer intends for Jews to follow Torah. These supersessionist views of Christ's fulfillment of the old covenant are rather commonplace in the tradition. G\&C's attempt to retain the theological concept of fulfillment while jettisoning the notion of a revocation or annulment of the covenant seems to me to align with aspects of two important thinkers for Jewish-Christian relations: Jules Isaac and R. Kendall Soulen. In the next sections, I connect Isaac's critique of certain Christian teachings on Judaism and Soulen's clarification of the concept of supersessionism with this important move in G\&C.

\section{Jules Isaac's Criticism of the Christian Teaching that the Law is "Fulfilled and Expired"}

Prior to the Second World War the claim that Christ supersedes Judaism was universally regarded as self-evident and unproblematic. Since the Second World War, however, the use of term "supersedes" has undergone a dramatic change. Increasingly, "supersede," as well as supersessionism, have come to be used as labels that identify a theologically inadequate or problematic Christian understanding of Jews and Judaism. G\&C provides yet another example of a post-war critique of the terms "supersede." Among other influences, this change was encouraged by the work of the French-Jewish historian and Holocaust survivor Jules Isaac (1877-1963). I do not have the space to trace the history of the language of supersessionism, but I want to focus on the relevance of Isaac's critique of the traditional conception of how Christ fulfills the Mosaic Law.

In the decades after the Shoah, the dominant categories for the postHolocaust examination of Christian teaching were anti-Judaism and antisemitism. $^{31}$ The term supersessionism was not yet widely used. It appears that the first

\footnotetext{
31 Gregory Baum, Is the New Testament anti-Semitic?:A Re-examination of the New Testament (Mahwah, NJ: Paulist Press, 1965); Rosemary R. Ruether's Faith and Fratricide: The Theological Roots of Anti-Semitism (Minneapolis: Seabury, 1974); Samuel Sandmel, Anti-Semitism in the New Testament? (Minneapolis: Fortress Press, 1978); John G. Gager, The Origins of Anti-Semitism: Attitudes toward Judaism in Pagan and Christian Antiquity (New York: Oxford University Press, 1985); George M. Smiga, Pain and Polemic: Anti-Judaism in the Gospels (Mahwah, NJ: Paulist Press,
} 
use of "supersede" as a term to describe a Christian teaching about Judaism occurred in English translations of the groundbreaking work of Isaac. ${ }^{32}$ While on the run from the Nazis, hiding in farms and at the homes of priests or ministers, Isaac wrote his groundbreaking 600-page study of antisemitism in the Christian tradition, Jésus et Israël. ${ }^{33}$ By means of meticulous historical research, the study unearthed the intellectual underpinnings supporting negative Christian views of Jews and Judaism, such as the deicide charge and the idea that Judaism was a degenerate religion. $^{34}$

Throughout Jésus et Israël, Isaac is determined to identify and challenge a "special kind of exegesis" 35 that had not only portrayed Judaism as a degenerate faith but had distorted Christianity as well. Isaac was adamant that this tradition of exegesis was to be distinguished from true Christian faith: "It must be clearly understood, that to oppose the teaching of contempt is not to oppose a doctrine essential to the Christian faith." 36 For Isaac, it was this "teaching of contempt" that required reexamination, not normative Christian faith: "The object of our attack is a tradition, time-honored and therefore all the more powerful, influential, and destructive, but in no way normative ....,37

In his 1962 book L'enseignement du mépris (translated into English in 1964 as The Teaching of Contempt: Christian roots of anti-Semitism), Isaac is concerned to challenge the traditional Christian claim that the coming of Christ entails the abrogation of Jewish law. It is here, for the first time in English, that

1992); William R. Farmer, Anti-Judaism and the Gospels, 1st ed. (Harrisburg, PA: Trinity Press International, 1999); Reimund Bieringer, Didier Pollefeyt, and Frederique Vandecasteele-Vanneuville, Anti-Judaism and the Fourth Gospel, 1st ed. (Louisville, KY: Westminster John Knox Press, 2001).

${ }^{32}$ Isaac had been a high-ranking French government official, World War I veteran, and professor of history. After the Nazi occupation of France, he was removed from his post as Inspector General of Education by the Vichy government. He then began writing a book investigating the roots of antisemitism. In 1943, while away from home, his daughter, son-in-law, and several family members were seized and killed by the Nazis. Stephen Plant, "Jules Isaac," A Dictionary of Jewish-Christian Relations, Edward Kessler and Neil Wenborn, eds. (New York: Cambridge University Press, 2008), 214. See the biographical notes written by Claire Huchet Bishop in Jules Isaac, Has Anti-Semitism Roots in Christianity? Translated by Dorothy Parkes and James Parkes. 1st printing (New York: National Conference of Christians and Jews, 1962), 27-34. Bishop's notes on Isaac are also in the English translations of Isaac's most influential work, The Teaching of Contempt: Christian Roots of AntiSemitism. Translated by Weaver Helen. 1st ed. (New York: Holt, Rinehart and Winston, 1964), 3-15; and his Jesus and Israel 1st ed. (New York: Holt, Rinehart and Winston, 1971), xi-xvii.

${ }^{33}$ Jules Isaac, Jésus et Israël (Nouv. éd. Paris: Fasquelle, 1959).

${ }^{34}$ Huchet, preface to Jesus and Israel, xiv; “A Biographical Introduction," 9. Isaac's historic rebuttal of antisemitic Christian ideas about Jews would become the basis for the 1947 statement now considered the "first fruit" of the new era of Jewish-Christian relations, "Ten Points of Seelisberg." See John Connelly, From Enemy to Brother: The Revolution in Catholic Teaching on the Jews, 1933-1965 (Cambridge, MA: Harvard University Press, 2012), 176.

${ }^{35}$ The Teaching of Contempt, 34.

${ }^{36}$ The Teaching of Contempt, 34.

${ }^{37}$ Isaac, The Teaching of Contempt, 35. Isaac argued the "teaching of contempt" was manifested in three main themes in the Christian tradition: 1) the dispersion of the Jews; 2) the degenerate state of Judaism; and 3) the crime of deicide. 
an author employs the term "supersede" to indicate a problematic conception of how Christ fulfills the Mosaic Law.

For Isaac, Christian views of Judaism as degenerate are deeply rooted in a tradition of apologetics that claimed the law was obsolete after Christ and that the Jews were attached to the law because they were "carnal beings":

This contention has its source in the earliest Judeo-Christian controversies over the Torah - the Law of Moses - and its observances. The Christian apologists maintained that with the coming of Christ, the Law had been fulfilled and superseded [accomplie et dépassée]. They taught that the Jews were attached to the letter and not the spirit of the law because they were "carnal" beings, blinded by Satan, incapable of understanding the real meaning of their own Scriptures. 38

Three times in Jésus et Israël, Isaac challenges the claim that Christ's fulfillment of the law also entails its obsolescence. ${ }^{39}$ However, instead of accomplie et dépassée ("fulfilled and obsolete"), the terms used in L'Enseignement du Mépris, in Jésus et Israël he uses accomplie et périmé ("fulfilled and expired"). Each time, the term périmé is rendered "superseded" by the English translator, though "supersede" is not a literal translation of Isaac's term périmé. ${ }^{40}$ Rather, "supersede" is used by the translator to convey what Isaac says is the double sens or double meaning of the traditional Christian concept of Christ's fulfillment of the Jewish law. Isaac uses these formulas to describe this double meaning: "fulfilled and obsolete (dépassée)" or "fulfilled and expired (périmé)."

The first occurrence of "supersede" in Jésus et Israël appears in a chapter entitled "Proposition 9: Jesus was born and lived 'under the law.' Did he intend or announce its abrogation [l'abrogation]? Many writers hold that he did, but their statements exaggerate, distort, or contradict the most important passages in the gospels." In this chapter, Isaac critically examines the modern French interpretation of Christ's fulfillment of the law. In particular, Isaac takes issue with the traditional claim that fulfillment of the law also means that it is périmé or expired: ${ }^{41}$

Fulfill — what a magnificent vista this verb opens to the theological imagination! . . . "The law will be 'fulfilled' [accomplie] in the double meaning of raised to perfection and superseded [double sens d'élevée à la perfection et de périmé]," in the words of F. Ménégoz. Somewhat more cautiously (in style, that is), Father Bonsirven says, "The New Covenant and its economy

\footnotetext{
${ }^{38}$ For the citations of these important terms referring to fulfilment of the law I provide the French text and the English translation. Isaac, Teaching of Contempt, 75. [Emphasis mine]; L'Enseignement de Mépris, 67.

${ }^{39}$ Isaac, Jésus et Israël, 428.

${ }^{40}$ L'Enseignement du Mépris was translated into English by Claire Huchet Bishop.

${ }^{41}$ Isaac, Jesus and Israel, 49; Jésus et Israël, 96.
} 
do not suppress those that came before but 'fulfill' them, as does the fruit into which the flower is transformed."

A second discussion of supersession comes at the end of this chapter, where Isaac refers once again to the double sens of fulfillment:

If Jesus had really been the revolutionary against the Law that he had been called; if he had presented himself as a 'destroyer of Judaism' . . . if he had let it be understood - in any way - that the whole of the Law was 'fulfilled' [accomplie] in his person and was thenceforth 'superseded' [périmé] in Ménégoz's phrase ... how is it that Jesus' most intimate disciples . . . and hundreds of thousands of converted Jews made not one allusion to it, seemed to know absolutely nothing about it? ${ }^{43}$

In the third and last occurrence of the concept of supersession in Jésus et Israël of which I am aware, Isaac cites the Christian teaching that Jewish law had expired as a principal cause of the widening gulf between Synagogue and Church in the first century:

It is again an indisputable fact . . o of capital importance for religion and for history that in this same period when the Gospel tradition was put down in writing, a gulf was opening between the Synagogue and its emancipated daughter, the Church. Jews rigorously faithful to the ancient Law and Christians who were breaking away from it, who declared it superseded [périmé], became adversaries, sometimes (the theologians, especially the doctors) mortal enemies. $^{44}$

The English term "supersede" is used to translate Isaac's criticism of what he viewed as the double sens of Christ's fulfillment of the law: "fulfilled and obsolete (dépassée)" or "fulfilled and expired (périmé)." Therefore, when "supersede" is first used to designate a problematic Christian view of Judaism in English theology it is used to name a very specific theological concept: After the passion of Christ, Jewish law is fulfilled according to its inward spiritual intention and therefore expired according to its outer ceremonial form. It is, in short, fulfilled and therefore obsolete. Isaac offered clarity on this term that others do not.

In the years following the translation of L'Enseignement du Mépris and Jésus et Israël into English, one finds instances of "supersede," as well as "supersession," beyond the works of Jules Isaac. The term is increasingly used in contemporary theology to designate problematic Christian claims about Juda-

\footnotetext{
${ }^{42}$ Isaac, Jesus and Israel, 64; Jésus et Israël, 118.

${ }^{43}$ Isaac, Jesus and Israel, 71 [Emphasis mine]; Isaac, Jésus et Israël, 125.

${ }^{44}$ Isaac, Jesus and Israel, 294. [Emphasis mine]
} 
ism. ${ }^{45}$ Scholars now stress that Christ and the Church do not supersede Israel. However, as I mentioned above, confusion and ambiguity now plague this term. This is in part because the term is no longer associated with the "double sense" of fulfillment it was given in Isaac's works. The lack of careful attention to the meaning of the term tends to create a vacuum that attracts scholars' perceptions of "negative Christian views of Judaism." How can the term "supersede" be kept from blurring into abstraction, making it vulnerable to dismissal as another "ism"? One way is to remain attentive to the fact that the word emerged in the context of Isaac's criticism of the "double sense" of Christ's fulfillment of the law (fulfilled and thenceforth expired).

Indeed, the scholar who has undertaken the most careful systematic theological treatment of the concept of supersessionism in the Christian tradition argues that a concept not unlike Isaac's "double sense" of fulfillment is the "heart of supersessionism."

\section{Kendall Soulen's Economic Supersessionism and its Similarity to Isaac's Critique}

R. Kendall Soulen is one of the first to attempt a careful definition and analysis of supersessionism. ${ }^{46}$ Significantly, Soulen's analysis coincides with Isaac's use of the term. Like Isaac, Soulen conceives of supersessionism as entailing a double sense of fulfillment and obsolescence. In fact, this is what he calls the "heart of supersessionism." 47

According to Soulen, the traditional Christian theology of the Jewish people needs to be seen in the context of a larger understanding of the narrative unity of the Christian canon as a whole. According to this larger narrative, "God chose the Jewish people after the fall of Adam in order to prepare the world for the coming of Jesus Christ, the Savior. After Christ came, however, the special role of the Jewish people came to an end and its place was taken by the church, the new Israel." ${ }^{48}$ As mentioned above, Soulen thinks supersessionism is most clearly manifested in this narrative framework in two forms, which he calls punitive and economic supersessionism. ${ }^{49}$ Of these, it is the second that will concern us most directly.

Punitive supersessionism is an approach to the biblical narrative that holds that God has abrogated God's covenant with Israel on account of Israel's rejection of Christ and the gospel. ${ }^{50}$ Because the Jews rejected Christ, God in turn

\footnotetext{
${ }^{45}$ Peter Ochs, Another Reformation: Postliberal Christianity and the Jews (Grand Rapids, MI: Baker Academic, 2011).

${ }^{46}$ Soulen, The God of Israel and Christian Theology.

${ }^{47}$ Soulen, "Israel and the Church," In Christianity in Jewish Terms, edited by Tikva Frymer-Kensky, et al. (Boulder, CO: Basic Books, 2002), 47.

${ }^{48}$ Soulen, The God of Israel and Christian Theology, 2.

${ }^{49}$ Soulen, The God of Israel and Christian Theology, 1.

${ }^{50}$ Soulen, The God of Israel and Christian Theology, 30.
} 
rejected them and revoked their covenant. "These Christians taught that God's covenant with the Jews was over, and that henceforth the church alone stood in its place." Soulen points out that supersessionism in this form speaks of God "revoking" the covenant as a punishment for sin. It is this form of supersessionism that we see rejected in G\&C.

Like punitive supersessionism, economic supersessionism also teaches that God has replaced Israel with the Church. But economic supersessionism does not occur because of Jewish disobedience or $\sin ^{52}$ Rather, the church replaces Israel because Christ's fulfillment of Jewish ceremonial law renders its continued observance obsolete. The Mosaic Law prepared humanity for redemption primarily by pointing forward to Christ in "a carnal and prophetic way," and the New Testament testifies to redemption in Christ in a "definitive and spiritual way.",53 "Circumcision, promises, law, temple, Israel's history, and so forth all point in various ways toward Christ and the church." ${ }^{, 54}$ With the advent of Christ, the prefiguring function of the carnal ceremonies or sacraments (such as circumcision) are superseded by new sacraments (such as baptism): "the prophecies, types, and figures of the Old Testament are fulfilled and superseded by their New Testament equivalents. $" 55$

Soulen's analysis of economic supersessionism is especially notable because it shares key features of Isaac's description of the traditional fulfillment concept, namely the idea of Jewish law as "fulfilled and obsolete." Soulen's concept of economic supersessionism overlaps significantly with at least two of Isaac's insights: 1) fulfillment carries a "double sense" in much Christian tradition (fulfilled and thenceforth superseded); 2) fulfillment understood according to this "double sense" inevitably undermines the theological rationale of Jewish existence.

First, recall that Isaac identified the double-sense concept - that the Jewish law had been "fulfilled and thenceforth expired"-as the root of the Christian view that Judaism is a degenerate religion. Soulen identifies this same concept as "the heart" of economic supersessionism when he describes a "double movement" of "fulfillment and cancellation" or "fulfillment and outer obsolescence." Soulen appeals to a variety of metaphors to illustrate the point:

The heart of economic supersessionism . . . simply affirms a double movement of inward fulfillment and outer obsolescence, like a butterfly that casts off its chrysalis. The chrysalis is not 'revoked' or repudiated, nor is there any

\footnotetext{
${ }^{51}$ Soulen, "Israel and Church," 171. This essay is perhaps the best introduction to Soulen's view of the church and its relationship to traditional supersessionist interpretations of Israel.

${ }^{52}$ The term "economy" (from oikonomia) refers to the traditional understanding of God's overarching redemptive work, or management, of two dispensations of the household of creation, Old and New.

${ }^{53}$ Soulen, The God of Israel and Christian Theology, 27.

${ }^{54}$ Ibid.

${ }^{55}$ Soulen, The God of Israel and Christian Theology, 28. [Emphasis mine]

${ }^{56}$ Soulen, "Israel and Church," 47.
} 
violation of the true organic continuity between caterpillar and butterfly. However, the chrysalis is rendered obsolete, and its retention would obviously be a serious mistake. The thought process is different from punitive supersessionism, but the destination is the same, insofar as both evacuate Israel's observance of the cultic law of positive theological significance. ${ }^{57}$

The double movement of fulfillment and cancellation can also be understood via the metaphor of a sculptor who sketches a figure on paper before sculpting the actual figure. Although the sculptor intends that the sketch of the figure play a crucial role in bringing about the ultimate aim of the project, the primary purpose of the sketch becomes obsolete with the appearance of the completed sculpture of the figure. ${ }^{58}$ For both Isaac and Soulen, the traditional concept of Christ's fulfillment of Judaism and Jewish law carries a double meaning. Soulen refers to this double meaning with the phrase "fulfilled and cancelled"; Isaac with the phrase "fulfilled and thenceforth expired."

Second, both scholars draw attention to the fact that the traditional double sense of fulfillment inevitably undermines Jewish existence, which can only maintain itself over time through the practice of Judaism. The Christian teaching that law is obsolete ultimately implies that the Jewish people itself is obsolete, that God no longer desires its continuation as a distinct people among the nations. $^{59}$

However, the idea that the obsolescence of Israel's existence is a theological problem may not be immediately apparent. One might object that Jews could continue as a mere ethnic group and still be Jews. But this would be a complete misunderstanding of that which is essential about Judaism. ${ }^{60}$

Judaism is the religion of the Jewish people, which represents a kind of ethnicity - a family descended from Abraham, Isaac, and Jacob that reproduces itself from generation to generation through the practice of ceremonial law and matrilineal descent. However, Judaism does not comprise an ethnicity as this term is understood in contemporary English discourse, where it functions as a polite synonym of race and is understood to be largely a function of hereditary. The Jewish people is essentially religious since it is first and foremost a covenanted people bound to God in part through God's gift of Torah.

The observance of Torah grows out of Israel's election. According to Jacob Neusner, those who observe the Torah maintain the covenant. To practice Judaism means "to act out in behavior and belief the key stories that are told in the Torah . . . the instruction set forth by God to Israel at Mount Sinai."61 Significantly, the religious practices of Judaism maintain the Jewish people: "What holds

\footnotetext{
${ }^{57}$ Personal correspondence. March 2011. [Emphasis mine]

${ }^{58}$ Paraphrase of Soulen's metaphor in "Israel and Church," 171. The image itself is used by several ancient Christian writers, including Melito of Sardis.

${ }^{59}$ Soulen, The God of Israel and Christian Theology, 4.

${ }^{60}$ Jacob Neusner, Judaism: The Basics (London/New York: Routledge, 2006).

${ }^{61}$ Ibid., 11.
} 
some descendants of Abraham and Sarah together as a people is the religion of Torah-observance, and this is true also of the many who do not themselves pay much attention to the mitzvoth."62

The idea that Jewish law is obsolete because it has "done its job" by pointing to Christ's passion throws into question God's desire that Jews exist at all. Since God's election of the Jewish people is expressed through Torah-observance (including circumcision, dietary laws, and Sabbath), the traditional claim that Christ has discontinued these practices is equivalent to saying God no longer desires the practice of Judaism. If God no longer desires Torah-observance, God no longer desires for there to be Jews in the world. This insight explains why Isaac and Soulen understand the economic form of supersessionism (fulfilled and expired; fulfilled and cancelled) to undermine the "very existence of Jewish flesh or carnal Jewish existence." 63

\section{Conclusion: Why Economic Supersessionism is a Theological Problem}

In this last section I want to explain why the belief that the ceremonial law is obsolete for Jews after the passion of Christ is a problem for both Jews and Christians. On this point, the theological work of the late Michael Wyschogrod is especially helpful. Reflection upon the nature of this problem can help us see more clearly what it might mean to answer G\&C's call to reject supersessionism.

For Wyschogrod, the central tenet of biblical faith is that God loves and elected the people of Israel "unto the end of time." 64 Circumcision is "a searing of the covenant into the flesh of Israel and not only, or perhaps not even primarily, into its spirit." 65 This covenant is maintained through circumcision and observance of Torah. Since the covenant is maintained through circumcision, the teaching that this custom is no longer a theologically significant act entails that God has repudiated God's promise to the Jewish people. ${ }^{66}$ And this is why economic supersessionism is a deep theological problem for Christians, not to mention deeply troubling for Judaism: Such a claim raises questions about God's trustworthiness and the trustworthiness of God's promises. If God desires that circumcision become obsolete for Jews, this implies that God desires that Jews

\footnotetext{
${ }^{62}$ Robert Jenson, "Toward a Christian Theology of Judaism," in Jews and Christians: People of God, ed. Carl Braaten et al. (Grand Rapids, MI: William B. Eerdmans Pub. Co, 2003), 9.

${ }^{63}$ Soulen, The God of Israel and Christian Theology, 31.

${ }^{64}$ Michael Wyschogrod, Abraham's Promise (Grand Rapids, MI.: William B. Eerdmans, 2004), 6.

${ }^{65}$ Michael Wyschogrod, The Body of Faith: God and the People Israel (Lanham, MD: Rowman \& Littlefield Publishers, Inc., 2000), 66.

${ }^{66}$ For Wyschogrod, such a problematic view of the election of the Jewish people is expressed not only in the church's attitude toward Jewish observance of Torah. Wyschogrod also thinks it is manifested in how Christians perceive the Jewish identity of baptized Jews. For Wyschogrod, if the church truly believes in "the permanence and centrality of Israel's election as central to its own identity, it will expect baptized Jews to continue to affirm their Jewish identity and continue to observe Torah." However, "if the church truly believes that it has fundamentally superseded God's covenant with Israel, it will prohibit baptized Jews from obeying Torah and maintaining a distinct identity within the church" (Wyschogrod, Abraham's Promise, 17).
} 
disappear from the world (or is at least indifferent to this result). Wyschogrod argues that such a low view of the Jewish people goes hand-in-hand with the idea that the disappearance of Jews from the world is "no theological loss":

Were all Jews to recognize the truth [of Christianity], they would cease their stubborn insistence on continuing to exist as an identifiable people and become an integral part of the new Israel-the Church-which is God's new covenant partner in the world. The disappearance of the Jews from the world would be no theological loss because their place would have been taken by the new people of God. ${ }^{67}$

For Wyschogrod, the Christian belief in the fulfillment and obsolescence of the ceremonial law is a problem because it means God, contrary to his promise, no longer desires for Jews to exist in the world as Jews, and that, consequently, God's promises cannot be trusted. ${ }^{68}$ Wyschogrod's understanding of the election of Israel makes clear why the Christian teaching that Jewish observance of the law is obsolete after Christ calls into question the faithfulness of God. ${ }^{69}$ Wyschogrod helps us see that economic supersessionism must be overcome, because to hold to this teaching means ultimately that God cannot be trusted.

As Philip Cunningham has pointed out, "it was not until Nostra Aetate rejected the notion of collective Jewish guilt for the crucifixion of Jesus . . that the foundations of supersessionism were overturned." ${ }^{70}$ The CRRJ's 1985 teaching that we "rid ourselves of the traditional idea of [the Jewish] people punished," combined with the rejection of replacement theology in G\&C make the overturning of supersessionism explicit.

\footnotetext{
${ }^{67}$ Ibid.

${ }^{68}$ David Novak explains the consequences of this point from the Christian perspective rather succinctly: "For Christians, the answer, paraphrasing Karl Barth, goes something like this: The promises God made through Jesus presuppose that God has already been keeping his promises to Israel. Indeed, for Christians, Jesus was sent to fulfill God's ultimate promise to Israel of redemption and then to extend it to the world. Nevertheless, God's initial promise to Israel is that she will not die but live, and live with duration as a covenanted people. The promises made through Jesus, which the Church accepts as normative, cannot be believed, therefore, if the Jewish people, who have a perpetual claim to be called Israel, are no longer present in the world" (Novak, Talking with Christians, 11).

${ }^{69}$ For a Christian description of this concern, see the work of Robert Jenson: “. . . identifiable Jewishness does not long survive within the gentile dominated church. To be sure, identifiable continuing descent from Abraham and Sarah is perhaps more likely within the church than among those assimilated into the secular world. But even so, if God is to have a people identified by descent from Abraham and Sarah, the church as it is will not provide it. I propose to my fellow Christians that God wills the Judaism of Torah-obedience as that which alone can and does hold the lineage of Abraham and Sarah together during the time of detour...By this time, the world is surely full of biological descendants of Abraham and Sarah who are not jointly part of any recognizable people. What holds some descendants of Abraham and Sarah together as a people is the religion of Torah-observance, and this is true also of the many who do not themselves pay much attention to the mitzvoth" (Jenson, "Toward a Christian Theology of Judaism," 9).

${ }^{70}$ Cunningham, 29.
} 
However, it is important for the Catholic-Jewish dialogue to recognize that the CRRJ has only rejected the punitive form of supersessionism. The CRRJ has yet to address economic supersessionism, which is clearly manifested in the commonplace medieval doctrine of the cessation of the law. This form of supersessionism is also present in modern Catholic teaching. One of the most concise examples occurs in Pope Benedict XVI's Many Religions, One Covenant: "[T]he Sinai covenant is indeed superseded. But once what was provisional in it has been swept away, we see what is truly definitive in it." ${ }^{71}$ As David Berger has rightly pointed out, this view is a restatement of pre-modern Christian doctrine. ${ }^{72} \mathrm{Mi}$ chael Wyschogrod thought this form of supersessionism was more pernicious than punitive supersessionism because of how it subtly calls into question the religious core of Judaism. Isaac and Soulen can serve as resources for clarifying the meaning of supersessionism in the Catholic-Jewish dialogue. In the light of their insightful commentary, we can see that supersessionism is not simply a term of abuse, or a manifestation of intractable disagreement among Jews and Christians. Indeed, the traditional way of speaking about Christ's fulfillment of the law actually calls into question the faithfulness of God for Jews as well as Christians.

\footnotetext{
${ }^{71}$ Joseph Ratzinger, Many Religions, One Covenant: Israel, the Church, and the World (San Francisco, CA: Ignatius Press, 1999), 70-71.

${ }^{72}$ Berger, 380.
} 